\title{
Зоран Сретеновић
}

Министарство просвете, науке и технолошког развоја

- Школска управа Крагујевац

Стручни рад

УДК: 796/799-057.87:373.3/.4 doi: $10.5937 /$ gfsfv $1623029 \mathrm{~S}$

\section{СПОРТ У ШКОЛСКОЈ ПРАКСИ}

\section{SPORT IN SCHOOL PRACTICE}

\section{Сажетак}

Главни циљ овог рада је да представи школску праксу у реализацији спортских такмичења у основним школама града Крагујевца и усмери његов развој у правцу остварења посебног циља из Националне стратегије развоја спорта у Републици Србији 2014. до 2018. године, на развој спорта деце и омладине. Истраживање је спроведено у 22 основне школе града Крагујевца. Подаци о учешћу школа на текмичењима узети су из извештаја савеза о реализацији такмичења у школској 2015/16. године. Школска спортска такмичења за ученике првог циклуса није усвојена пракса школа. На свим такмичењима наступило је 335 дечака и 393 девојчица. Најмасовније такмичење је у пливању на коме је наступило 286 основаца, затима атлетика са 171 и одбојка са 173 такмичара. Укупан проценат учешћа школске популације на такмичењима у организацији Градског савеза за школски спорт у школској 2015/16. години у мушкој конкуренцији је 4,90\%, док је тај проценат у женској конкуренцији 5,84\%. Школа у оквиру школског програма, сачињава програм школског спорта и спортских активности, у који треба уврстити сва такмичења прописана планом и програмом физичког васпитања, програм недеље школског спорта, спортске манифестације и приредбе у организацији локалне самоуправе и план наступа на такмичењима у организацији градског савеза за школски спорт. Имајући у виду значај физичких активности са аспекта социјалне и здравствене улоге у неговању и јачању здраваља деце и омладине, треба формирати међуресорни тим у чији састав би ушли преставници Министарства просвете, спорта и здравља, са задатком координације активности за унапређење наставе физичког васпитања и спорта.

КљУчне речи: СТРАТЕГИЈА / РАЗВОЈНИ ЦИљ / ПОДРШКА / САРАДњА / РЕАЛИЗАЦИЈА 


\section{Summary}

The primary aim of this work is to present the school practice in realization of sport competitions in Primary Schools in the city of Kragujevac and to direct the sport and youth development towards the objective achievement from the Sport Development National Strategy of the Republic of Serbia from 2014 to 2018. The research was conducted in 22 primary schools of the city of Kragujevac. Participation of the school competition data was taken from the Association competition realization report for the school year 2015/2016. School sport competitions for the students of the first cycle of the elementary education are not the research implied primary schools praxis. Within the school curriculum, school constitutes the school sport and sport activities program which should contain all the competitions prescribed by P.E and P.E Chosen Sport curriculum, School sport week's program, sport manifestations and events organized by the Local Government and the performance plan for the competitions organized by the School Sports City Association. Considering the significance of the physical activity from the aspect of social and health function in care and strengthening of the children and youth health, the interagency team which should consist of Ministry of Education, Sport and Health members should be formed, with the mission to coordinate the activities for the promotion P.E and sport.

Key words: STRATEGY/DEVELOPMENTOBJECTIVE/SUPPORT/COOPERATION / REALIZATION

Увод

На основу резултата истраживања којим се потврђују позитивни утицаји квалитетно реализованих програма физичког васпитања, посебно у млађем школском узрасту, креирана је национална Стратегија развоја спорта у Републици Србији, која у први план ставља потребу да се код деце негује и развија навика за редовно бављење спортом и физичким вежбањем. Један од општих циљева стратегије је унапређен школски спорт. Посебни циљеви унапређења школског спорта су: побољшани материјално-технички услови за реализацију школског спорта; повећан број спортских секција и других ваннаставних спортских и рекреативних активности у оквиру школског спорта; повећано учешће ученика на школским спортским такмичењима, приредбама и манифестацијама; побољшан стручно педагошки рад и унапређена институционална сарадња у оквиру школског спорта; подстакнуто значајније укључивање локалне самоуправе у реализацију и унапређење школског спорта и побољшано медијско праћење и промоција школског спорта у циљу неговања културе спортског понашања, фер плеја, сарадње, толеранције и поштовања различитости на спортским теренима и поред њих.

Школа организује и спроводи спортска такмичења, као интегрални део процеса наставе физичког васпитања, према плану стручног већа и то: обавезна унутаршколска и међуодељенска такмичења у: гимнастици (у зимском периоду), атлетици (у пролећном периоду) и најмање у једној спортској игри (у току године). Према програму наставе физичког васпитања реализују се активности у природи 
и курсни облик наставе, обавезни програм: јесењи и пролећни крос и зимовање за време зимског распуста на коме се ученици обучавају смучању, клизању и реализују излети на смучкама или санкама. Стручно веће сачињава план и програм унутаршколских и спортских такмичења ученика Србије, као могући део плана рада школе, на почетку школске године и спроводи га током целе године у складу са материјалним и просторним условима школе. План и програм ванчасовних и ваннаставних активности се, на предлог стручног већа, усваја као део годишњег програма рада школе (Просвейни гласник, 2007).

Унутаршколска такмичења организује се и за ученике првог циклуса основног образовања и васпитања, у гимнастици (у зимском периоду), атлетици (у пролећном периоду) и најмање у једној спортској игри (у току године), програм сачињава и спроводи стучни актив. Стручни актив и школа план и програм унутаршколских такмичења прилагођава, поред осталог, и предложеном календару школских спортских такмичења од стране Савеза за школски спорт (Просветни гласник, 2013).

Закон о основном образовању и васпитању у члану 40. прописује: „Ради развоја и практиковања здравог начина живота, развоја свести о важности сопственог здравља и безбедности, о потреби неговања и развоја физичких способности, као и превенцији насиља, наркоманије, малолетничке делинквенције, школа (у оквиру школског програма) реализује и програм школског спорта, којим су обухваћени сви ученици. Школа је дужна да, у оквиру програма школског спорта, заједно са јединицом локалне самоуправе, организује недељу школског спорта најмање једном у току полугодишта. Недеља школског спорта обухвата такмичења свих ученика у спортским дисциплинама прилагођеним узрасту и могућностима ученика" (Просветни гласник, 2013).

Неопходност да се приступи темељитом решавању проблема физичког образовања и васпитања у првом циклусу основног образовања, експлицитно је поставила стручна јавност Немачке (Brettschneider \& Brandl-Bredenbeck 2008). Полазећи од резултата истраживања у вези са недовољном физичком активношћу и гојазноси деце млађег школског узраста, немачки стручњаци сматрају да проблем мора бити евалуиран с аспекта ефикасности рада наставника разредне наставе. Наводе да будућа дискусија о томе да ли здравствени проблеми потомства, која ће бити последица недовољне активности и моторичког дефицита, имају већи значај од педагошког приципа у вези са радом наставника разредне наставе. Да је проблем недовољне физичке активности достигао ниво националних размера у Србији, показује доношење Уредбе о Националном програму превенције, лечења и контроле кардиоваскуларних болести у Републици Србији до 2020. године. У наведеној Уредеби здравствена струка као једну од превентивних мера препоручује да се у плановима за физичко васпитање повећа обим физичких активности у оквиру школског програма. Истраживање националног Института за јавно здравље ,Др Милан Јовановић Батут", из 2013. показало је да сваки пети ученик у Србији има лоше телесно држање, код 15,4\% ученика регистрован је неки деформитет кичме, а лоше обликована стопала има чак $17,6 \%$ ученика. Осим са кичмом и стопалима, 
деца све чешће имају проблем и са гојазношћу: петина деце узраста од 7-19 година има прекомерну телесну тежину, показали су систематски прегледи. Телесна развијеност ученика кроз дужи низ година задржава се на незавидном нивоу према налазу стручњака Института „Батут”, чак 18,4\% деце школске популације је са незадовољавајућом развијеношћу. То значи да свако пето дете школског узраста показује одступање у телесној развијености, висини и тежини. У односу на 1995. годину, дечаци су данас физички мање активни за $6 \%$, девојчице за $12 \%$. У односу на 1995. годину, данашњи дечаци су виши за $3 \%$ и тежи за $14 \%$, док су девојчице више за $2,5 \%$ и теже за $11 \%$.

Значај спортских активности у слободно време за психички, когнитивни и социјални развој младих препознат је у већини савремених друштава. Посебна вредност бављења спортом деце препозната је и због превенције од различитих болести зависности и социјално девијантних понашања, као што је наркоманија, алкохолизам, различити облици насилног понашања и деликвентног понашања. Бројним научним радовима потврђено је да физичка активност повољно утиче на функционалну способност, мишићну снагу, телесну масу, густину коштаног ткива, крвног притиска, смањење анксиозности и стреса, као и повећење самопоуздања код деце и адолесцената. Адолесценција је период у развоју појединца када се развијају навике које, дугорочно посматрано, могу бити у функцији заштите здравља, као што је редовно вежбање и бављење спортом. Дугорочно гледано, физичко вежбање и бављење спортом су значајни показатељи усвајања и здравог стила живота адолесцената. (Mc Deviit, \& Ormarod, 2002).

Према „прогнози“ немачких стручњака, с обзиром на значај физичког васпитања и спорта у друштву, имајући у виду његову социјалну и здравствену улогу, без обзира на педагошки циљ, преовладаће потерба за јавним здрављем. Оно ће бити водећи подстицај за будући развој физичког и спортског образовања и васпитања (Радојевић, 2011).

Свако пето дете се бави спортом, мали број младих у слободно време чита књиге или прати догађаје из културе, а још мањи број бави се неким видом стваралачких активности. Оваква структура слободног времена може се оценити као сиромашна, а слободно време којим млади располажу као простор за промоцију вредности путем бављења спортским активностима.

Готово половина младих (47\%) слободно време проводи у неструктурираном дружењу са вршњацима. Поред вршњака, млади слободно време радо и често проводе уз телевизор ( $45,8 \%)$, уз мобилни телефон $(32,8 \%)$ или уз компјутер $(28,6 \%)$.

Проценат од $37,6 \%$ деце и младих је сагласно са тврдњом „Физичко васпитање у школи је лоше организовано па зато од њега нама користи", док се са тим не слаже $45,8 \%$, а $14,1 \%$ нема став о томе. Сагласност с овим мишљењем се видно повећава са узрастом (30,7\% на 54,4\%) (Извештај о остваривању права детета у Републици Србији из угла деце и младих, 2013). 
Због тога је веома важно у адолесценцији створити квалитетне услове за вежб́ање и бављење спортом, у чему настава физичког васпитања може да има велику улогу.

О спорту у школама се често доносе паушални и научно неутемељени судови, од крајње нагативних оцена материјалних услова рада, рада наставника и реализације програма школског спорта, преко констатације да је спорт у школама запостављен, па до позитивних оцена, који се заснивају на добрим примерима из праксе. Ми и не знамо поуздано какво нам је реално стање спорта у школској пракси.

Основни циљ овог истраживања био је да се дође до сазнања о ресурсима школа за рад спортских секција, обухвату ученика у спортским секцијама, реализацији спортских такмичења унутар школе и учешћу у систему текмичења у организацији градског савеза за школски спорт. На основу резултата истраживања потребно је преложити мере за унапређивање школског спорта и његов развој усмерити у правцу остварења једног од посебних циљева Националне стратегије развоја спорта у Републици Србији од 2014. до 2018. године, развој спорта деце и омладине - на развој школског спорта. Посебно, повећањем броја спортских секција и других ваннаставних спортских и рекреативних активности у оквиру школе, повећаног учешћа ученика на спортским такмичењима у школи, као и у систему Савеза за школски спорт.

\section{Метод}

\section{Ток и йосйуйак истираживања}

Истарживање је спроведено у току школске 2015/2016. године на основу непосредног увида у документа 22 основне школе града Крагујевца и то: школски програм и годишњи план рада. У оквиру школског програма сагледаван је садржај Програма школског спорта и спортских активности, а у оквиру Годишњег плана рада остварен је увид у: општи глобални план за реализацију наставе физичког васпитања, структуру радног времена наставника физичког васпитања и наставника разредне наставе, задужења наставника у недељној норми непосредног рада са ученицима за рад са спортским секцијама, распоред термина у сали или на спортским теренима за реализацију програма спортске секције, број ученика по разредима и полу, материјално-технички услови за наставу физичког васпитања, реализација спортских такмичења на нивоу школе, број спортских секција у школи, број дечака и девојчица у спортским секцијама, реализација јесењег и пролећног кроса. Број пријављених спортских секција за учешће у систему такмичења градског савеза за школски спорт утврђен је на основу пријава које су школе попуниле и доставиле, а број школа које су се такмичиле током школске 2015/16. године на основу извештаја о реализацији такмичења у организацији овог савеза. 


\section{Обрада йодат̄ака}

Подаци су обрађени стандардним процедурама дескриптивне статистике дистрибуција фреквенције и процентни рачун.

\section{Резултати}

Кадровски и майеријално-иеехнички услови за реализаџију сйорйа у иколи

Основно образовање и васпитање у 22 школе града Крагујевца стиче 13560 ученика, у првом циклусу је 6674, у другом 6886 ученика, од тога 3319 девојчица је у првом и 3414 у другом циклусу, 3355 дечака је у првом и 3472 у другом циклусу. Од укупног броја ученика, од наставе физичког васпитања и физичко васпитање изабрани спорт, ослобођено је 12 дечака и 17 девојчица.

Табела 1. Майеријално йехнички услови икола за реализацију сйорйа

\begin{tabular}{|c|c|c|c|c|c|}
\hline ШКОЛА & $\begin{array}{c}\text { Сала за } \\
\text { физичко }\end{array}$ & $\begin{array}{c}\text { Спољни } \\
\text { рукометни } \\
\text { терен }\end{array}$ & $\begin{array}{c}\text { Спољни } \\
\text { кошаркашки } \\
\text { терен }\end{array}$ & $\begin{array}{c}\text { Спољни } \\
\text { одбојкашки } \\
\text { терен }\end{array}$ & Базен \\
\hline ОШ „М. Тодоровић” & $24,3 \times 11,6 \mathrm{M}$ & не & не & не & не \\
\hline ОШ „Свети Сава” & $26 \times 14 \mathrm{M}$ & да & да & да & не \\
\hline ОШШ „М. Јовановић” & $30 \times 20 \mathrm{M}$ & да & да & не & не \\
\hline ОШ „С. Марковић” & $24 / 14 \mathrm{M}$ & не & да & не & $11,8 \times 5,7 \mathrm{M}$ \\
\hline ОШ „Р. Домановић” & $24 / 14 \mathrm{M}$ & да & да & He & не \\
\hline ОШ ,21. Октобар" & $24 \mathrm{x} 14 \mathrm{M}$ & да & да & да & не \\
\hline ОШ ,Д.Л. Шпанац” & $30 \mathrm{x} 17 \mathrm{M}$ & да & да & да & не \\
\hline ОШІ „С. Сремчевић” & $40 \times 24 \mathrm{M}$ & не & не & не & не \\
\hline ОШ „Д. Михаиповић” & $26 / 14 \mathrm{M}$ & да & да & да & не \\
\hline ОШ „В. Стефановић” & $24 \mathrm{x} 14 \mathrm{M}$ & да & да & да & $12 \times 3,8 \mathrm{M}$ \\
\hline ОШ „Ј. Поповић” & $24 / 14 \mathrm{M}$ & да & да & да & не \\
\hline ОШ „М. Станојловић” & $24 \times 14 \mathrm{M}$ & да & да & He & $\mathrm{He}$ \\
\hline ОШ „„Ђ. Јакшић” & $22 / 12 \mathrm{M}$ & да & да & да & не \\
\hline ОШ „Ј. Ђатић” & $33 \times 23 \mathrm{M}$ & не & да & да & не \\
\hline ОШ „М. Симовић” & Учионища & да & да & да & не \\
\hline ОШІ „Н. Недељковић” & Хол & да & не & да & не \\
\hline ОШІ „С. Младеновић” & Хол & да & да & да & не \\
\hline ОШ „Ж. ивац" & Сала 90м & да & да & да & не \\
\hline ОШ „19. Октобар" & Сала $120 \mathrm{M}$ & да & да & не & не \\
\hline ОШІ „П.С. Поповић” & Сала 90м & не & да & не & не \\
\hline ОШ „Д. Обрадовић” & Хол & не & да & не & не \\
\hline ОШ „ІІІ кг. батаљон” & Сала $18 x 8$ м & да & да & да & не \\
\hline
\end{tabular}


Укупан број наставника физичког васпитања из школа које су учествовале у овом истраживању износи 49; што се тиче њихове квалификационе структуре, највећи број 47 има VII/1 стручне спреме и 2 наставника су са VI степен стручне спреме. Салу за физичко васпитање и спољне спортске терене има 14 школа, 4 школе користе адаптирани простор и спољне спортске терене, а 4 школе располажу само са спољним спортским теренима. Две школе поседују јаму за скокове и затворени базен димензија 12×3.8м и $11.8 \times 5.7$ м (Табела 1$)$.

Табела 2. Број расйоложивих лоййи за сйорйске игре и јаме за скокове

\begin{tabular}{|c|c|c|c|c|c|}
\hline ШКОЛА & $\begin{array}{l}\text { ЛОПТЕ ЗА } \\
\text { РУКОМЕТ }\end{array}$ & $\begin{array}{l}\text { ЛОПТЕ ЗА } \\
\text { КОШАРКУ }\end{array}$ & $\begin{array}{l}\text { ЛОПТЕ ЗА } \\
\text { ОДБОЛКУ }\end{array}$ & $\begin{array}{c}\text { ЛОПТЕ ЗА } \\
\text { ФУДБАЛ }\end{array}$ & $\begin{array}{c}\text { JAME 3A } \\
\text { CКОКОВE }\end{array}$ \\
\hline ОШ „М. Тодоровић” & 5 & 5 & 5 & 2 & $\mathrm{HE}$ \\
\hline ОШІ „Свети Сава” & 12 & 10 & 6 & 10 & $\mathrm{HE}$ \\
\hline ОШ „М. Јовановић” & 8 & 10 & 15 & 5 & $\mathrm{HE}$ \\
\hline ОШ „С. Марковић” & 8 & 8 & 6 & 4 & $\mathrm{HE}$ \\
\hline ОШ „Р. Домановић” & 20 & 20 & 10 & 10 & $\mathrm{HE}$ \\
\hline ОШІ „21. Октобар” & 0 & 10 & 10 & 10 & ДА \\
\hline ОШ „д. Л. Шпанац” & 2 & 6 & 4 & 2 & $\mathrm{HE}$ \\
\hline ОШ „С. Сремчевић” & 2 & 5 & 6 & 2 & $\mathrm{HE}$ \\
\hline ОШ „Д. Михаиловић" & 5 & 10 & 10 & 6 & $\mathrm{HE}$ \\
\hline ОШІ „В. Стефановић” & 18 & 18 & 16 & 10 & $\mathrm{HE}$ \\
\hline ОШ „л. Поповић” & 10 & 10 & 10 & 10 & $\mathrm{HE}$ \\
\hline ОШ „М. Станојловић” & 3 & 7 & 10 & 5 & $\mathrm{HE}$ \\
\hline ОШ „Ђ. Јакшић” & 5 & 5 & 5 & 5 & $\mathrm{HE}$ \\
\hline ОШ „Ј. Ђатић” & 2 & 17 & 1 & 1 & $\mathrm{HE}$ \\
\hline ОШ „,М. Симовић” & 3 & 3 & 3 & 1 & $\mathrm{HE}$ \\
\hline ОШ „Н. Недељковић” & 2 & 5 & 2 & 2 & ДА \\
\hline ОШ „С. Младеновић” & 6 & 6 & 6 & 6 & $\mathrm{HE}$ \\
\hline ОШ „Ж. Дивац” & 6 & 4 & 4 & 2 & $\mathrm{HE}$ \\
\hline ОШІ „19. Октобар” & 4 & 2 & 15 & 1 & $\mathrm{HE}$ \\
\hline ОШ „П.С. Поповић” & 6 & 10 & 6 & 3 & $\mathrm{HE}$ \\
\hline ОШ „Д. Обрадовић” & 1 & 0 & 2 & 1 & $\mathrm{HE}$ \\
\hline ОШ „ПI кг. батаљон” & 10 & 10 & 10 & 10 & $\mathrm{HE}$ \\
\hline УКУПНО & 137 & 181 & 162 & 108 & 2 \\
\hline
\end{tabular}

Школама је на располагању 137 лопти за рукомет, 181 лопта за кошарку, 162 за одбојку, 108 лопти за фудбал и 2 јаме за скокове (Табела 2). 


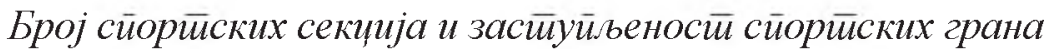

Од 49 наставника физичког васпитања, 4 (8,1\%) у структури 40-часовне радне недеље (непосредни рад са ученицима) немају задужења за рад са спортским секцијама. Од 45 који имају ово задужење, њих $23(51,11 \%)$ су задужени за рад са једном спортском секцијом, једним часом недељно, 17 (37,77\%) наставника реализује рад у 2 спортске секције са по два часа недељно, 3 (6,66\%) наставника ради са 3 спортске секције са по једним часом недељьно по секцији и $2(4,44 \%)$ ради са 4 спортске секције са 0,5 часа по секцији недељно. Сви наставници који су задужени имају обезбеђене термине за рад спортских секција у сали за физичко васпитање или на отвореним спортским теренима. Атлетика је најзаступљенија спортска грана, у 11 (50\%) школа постоји мушка атлетска секција у чији рад је укључено 105 дечака, а у $12(54,54 \%)$ школа женска атлетска секција у којима је 123 девојчице. Фудбал је заступљен у 10 (45,45\%) школа у којима вежба 138 дечака, 3 школе $(6,66 \%)$ имају женску фудбалску секцију у којима је 40 девојчица. Мушка кошаркашка секција постоји у 10 школа $(45,45 \%)$ у чији рад је укључено 134 дечака, док $3(6,66 \%)$ школе имају женску кошаркашку секцију у којој вежба 30 девојчица. Одбојкашка женска секција заступљена је у $9(43,43 \%)$ школа у чији рад је укључено 138 девојчица, мушка секција постоји у $3(6,66 \%)$ школе у којима вежба 46 дечака. Рукометна мушка и женска секција постоји у 1 школи $(2,22 \%)$ у чији рад је укључено по 12 дечака и девојчица. Стони тенис, као секција, постоји у $3(6,66 \%)$ школе у мушкој конкуренцији са 10 дечака и једној школи у женској конкуренцији са 5 девојчица. Стрељаштво у спортским секцијама заступљено је у 2 (4,44\%) школе у мушкој и женској конкуренцији са 8 дечака и 12 девојчица. Ритмиком могу да се баве девојчице у $3(6,66 \%)$ школе са обухватом од 15 девојчица. Интересантан је податак да у $5(11,11 \%)$ школа постоје секције за тренирање пливања мушке популације и чак у $6(13,23 \%)$ школа пливањем могу да се баве девојчице. У 2 школе пливањем се у оквиру спортске секције бави 27 дечака и 34 девојчице (Табела 3).

Табела 3. Реализачија иколских сйорйских йакмичења и кроса

\begin{tabular}{|c|c|c|c|c|}
\hline ШКОЛА & Атлетика & $\begin{array}{c}\text { Вежбе на } \\
\text { справама и тлу }\end{array}$ & Спортска игра & Крос \\
\hline ОШІ „М. Симовић” & I & I & $\begin{array}{c}\text { Мали фудбал } \\
\text { Кошарка } \\
\text { Одбојка } \\
\text { Стони тенис }\end{array}$ & $\begin{array}{c}\text { Јесењи } \\
\text { Пролећни }\end{array}$ \\
\hline ОШ „М. Тодоровић” & I & I & / & $\begin{array}{c}\text { Јесењи } \\
\text { Пролећни }\end{array}$ \\
\hline ОШ „Свети Сава” & Атлетика & I & $\begin{array}{c}\text { Мали фудбал } \\
\text { Кошарка } \\
\text { Одбојка } \\
\text { Рукомет }\end{array}$ & $\begin{array}{c}\text { Јесени } \\
\text { Пролећни }\end{array}$ \\
\hline ОШ „,Н. Недељковић” & I & I & I & 1 \\
\hline ОШ „М. Јовановић” & I & I & $\begin{array}{c}\text { Одбојка } \\
\text { Мали фудбал }\end{array}$ & $\begin{array}{c}\text { Јесењи } \\
\text { Пролећни }\end{array}$ \\
\hline
\end{tabular}




\begin{tabular}{|c|c|c|c|c|}
\hline ОШ „С. Марковић” & / & I & / & $\begin{array}{c}\text { Јесењи } \\
\text { Пролећни }\end{array}$ \\
\hline ОШІ „С..Младеновић” & I & I & $\begin{array}{c}\text { Мали фудбал } \\
\text { Одбојка }\end{array}$ & $\begin{array}{c}\text { Јесењи } \\
\text { Пролећни }\end{array}$ \\
\hline ОШ „Ж. Цивац" & / & I & $\begin{array}{c}\text { Кошарка } \\
\text { Стони тенис } \\
\text { Мали фудбал }\end{array}$ & $\begin{array}{c}\text { Јесењи } \\
\text { Пролећни }\end{array}$ \\
\hline ОШ „Р. Домановић” & I & / & 1 & I \\
\hline ОШ „,19. Октобар” & / & I & I & I \\
\hline ОШ „,21. Октобар” & I & I & I & I \\
\hline ОШ „д. Л.Шпанац” & / & I & $\begin{array}{c}\text { Мали фудбал } \\
\text { Одбојка }\end{array}$ & $\begin{array}{c}\text { Јесењи } \\
\text { Пролећни }\end{array}$ \\
\hline ОШ „С. Сремчевић” & / & I & $\begin{array}{c}\text { Кошарка } \\
\text { Мали фудбал } \\
\text { Одбојка }\end{array}$ & $\begin{array}{c}\text { Јесењи } \\
\text { Пролећни }\end{array}$ \\
\hline ОШІ „Д. Михаиловић” & / & / & $\begin{array}{c}\text { Мали фудбал } \\
\text { Одбојка }\end{array}$ & $\begin{array}{c}\text { Јесењи } \\
\text { Пролећни }\end{array}$ \\
\hline ОШІ „В. Стефановић” & / & I & I & I \\
\hline ОПІ „П.С. Поповић” & / & / & $\begin{array}{c}\text { Кошарка } \\
\text { Мали фудбал }\end{array}$ & $\begin{array}{c}\text { Јесењи } \\
\text { Пролећни }\end{array}$ \\
\hline ОШ „Ј. Поповић” & / & / & / & $\begin{array}{c}\text { Јесењи } \\
\text { Пролећни }\end{array}$ \\
\hline ОШ „Д. Обрадовић” & / & I & $\begin{array}{c}\text { Мали фудбал } \\
\text { Одбојка }\end{array}$ & $\begin{array}{c}\text { Јесењи } \\
\text { Пролећни }\end{array}$ \\
\hline ОШ „Ш кг.батаљон” & I & 1 & 1 & I \\
\hline ОШ „М. Станојловић” & I & I & / & I \\
\hline ОШ „Ђ. Јакшић” & / & / & / & $\begin{array}{c}\text { Јесењи } \\
\text { Пролећни }\end{array}$ \\
\hline ОШ „,. Ђатић” & I & / & $\begin{array}{c}\text { Мали фудбал } \\
\text { Одбојка }\end{array}$ & $\begin{array}{c}\text { Јесени } \\
\text { Пролећни }\end{array}$ \\
\hline
\end{tabular}

Генерално гледано, спортска грана која се најчешће јавља у оквиру унутаршколских такмичења је мали фудбал, у 11 (50,00\%) школа. Затим следе: одбојка у 8 (36,36\%) школа, кошарка у 5 ( 22,73\%) школа, стони тенис у $2(9,09 \%)$ школе и атлетика у 1 (4,54\%) школи. Индикативан је податак да се ни у једној школи не реализује такмичење из вежби на справама и тлу, а да $7(31,82 \%)$ школа не реализује јесењи и пролећни крос. Школско такмичење из атлетике организује једна $(4,54 \%)$ школа. У 6 (27,24\%) школа се не реализују школска спортска такмичења која су прописана наставним планом и програмом физичког васпитања (Табела 3). 
табела 4. Сйорйске гране у сйорйским секцијама у другом циклусу

\begin{tabular}{|c|c|c|c|c|c|}
\hline ШКОЛА & $\begin{array}{c}\text { Спортске } \\
\text { секције / Дечаци }\end{array}$ & $\begin{array}{c}\text { Спортска } \\
\text { секција } \\
\text { /девојчице }\end{array}$ & ШКОЛА & $\begin{array}{c}\text { Спортске } \\
\text { секщије / } \\
\text { дечаци }\end{array}$ & $\begin{array}{l}\text { Спортске } \\
\text { секщије / } \\
\text { девојчице }\end{array}$ \\
\hline ОШІ „М. Тодоровић” & $\begin{array}{c}\text { Атлетика } \\
\text { Пливање } \\
\text { Стрељаштво } \\
\text { Фудбал } \\
\text { Кошарка }\end{array}$ & $\begin{array}{c}\text { Одбојка } \\
\text { Ритмичка } \\
\text { гимнастика } \\
\text { Пливање } \\
\text { Атлетика }\end{array}$ & $\begin{array}{c}\text { ОШ „,М. } \\
\text { Станојловић” }\end{array}$ & Кошарка & Одбојка \\
\hline ОШ „Свети Сава” & $\begin{array}{l}\text { Фудбал } \\
\text { Кошарка }\end{array}$ & 1 & ОШ „Т. Јакшић” & $\begin{array}{c}\text { Атлетика } \\
\text { Гимнастика } \\
\text { Кошарка } \\
\text { Фудбал } \\
\text { Џудо } \\
\text { Теквондо }\end{array}$ & $\begin{array}{c}\text { Атлетика } \\
\text { Гимнастика }\end{array}$ \\
\hline ОШ „ М. Јовановић” & $\begin{array}{c}\text { Фудбал } \\
\text { Одбојка } \\
\text { Атлетика } \\
\text { Кошарка } \\
\text { Стони тенис } \\
\text { Пливање }\end{array}$ & $\begin{array}{c}\text { Фудбал } \\
\text { Одбојка } \\
\text { Атлетика } \\
\text { Кошарка } \\
\text { Пливање }\end{array}$ & ОШ „Ј. Ђатић” & $\begin{array}{l}\text { Атлетика } \\
\text { Одбојка }\end{array}$ & $\begin{array}{l}\text { Атлетика } \\
\text { Одбојка }\end{array}$ \\
\hline ОШ „С. Марковић” & $\begin{array}{c}\text { Стрељаштво } \\
\text { Стони тенис } \\
\text { Кошарка } \\
\text { Пливање } \\
\text { Атлетика }\end{array}$ & $\begin{array}{c}\text { Стрељаштво } \\
\text { Одбојка } \\
\text { Пливање } \\
\text { Атлетика }\end{array}$ & ОШ „М. Симовић” & $\begin{array}{c}\text { Фудбал } \\
\text { Пливање }\end{array}$ & Пливање \\
\hline ОШ „Р. Домановић” & Одбојка & 1 & $\begin{array}{c}\text { ОШ „Н. } \\
\text { Недељковић”, }\end{array}$ & $\begin{array}{c}\text { Атлетика } \\
\text { Фудбал }\end{array}$ & Атлетика \\
\hline ОШ „,21. Октобар” & $\begin{array}{c}\text { Атлетика } \\
\text { Кошарка } \\
\text { Фудбал }\end{array}$ & $\begin{array}{c}\text { Атлетика } \\
\text { Одбојка } \\
\text { Фудбал }\end{array}$ & $\begin{array}{c}\text { ОII „С. } \\
\text { Младеновић” }\end{array}$ & $\begin{array}{c}\text { Атлетика } \\
\text { Фудбал }\end{array}$ & $\begin{array}{c}\text { Атлетика } \\
\text { Фудбал }\end{array}$ \\
\hline ОШ ,„Д. Л.Шпанац" & $\begin{array}{c}\text { Атлетика } \\
\text { Копарка } \\
\text { Одбојка } \\
\text { Фудбал }\end{array}$ & $\begin{array}{c}\text { Атлетика } \\
\text { Кошарка } \\
\text { Одбојка } \\
\text { Фудбал }\end{array}$ & ОШ „Ж.Дивац" & $\begin{array}{c}\text { Стони тенис } \\
\text { Шах }\end{array}$ & $\begin{array}{c}\text { Стони тенис } \\
\text { Шах }\end{array}$ \\
\hline ОШ „С. Сремчевић” & $\begin{array}{c}\text { Фудбал } \\
\text { Кошарка } \\
\text { Атлетика }\end{array}$ & $\begin{array}{l}\text { Атлетика } \\
\text { Одбојка }\end{array}$ & ОШ „,19. Октобар” & / & $/$ \\
\hline $\begin{array}{c}\text { ОШ „Д. } \\
\text { Михаиловић", }\end{array}$ & Кошарка & $\begin{array}{c}\text { Одбојка } \\
\text { Пливање } \\
\text { Стрељаштво }\end{array}$ & ОШ „П.С. Поповић” & 1 & $\begin{array}{c}\text { Ритмичка } \\
\text { гимнастика }\end{array}$ \\
\hline OII „В. Стефановић” & $\begin{array}{c}\text { Атлетика } \\
\text { Фудбал } \\
\text { Одбојка } \\
\text { Кошарка }\end{array}$ & $\begin{array}{c}\text { Атлетика } \\
\text { Фудбал } \\
\text { Рукомет } \\
\text { Кошарка }\end{array}$ & ОII „Д. Обрадовић” & $\begin{array}{l}\text { Атлетика } \\
\text { Одбојка }\end{array}$ & Фудбал \\
\hline OІІ „Ј. Поповић” & $\begin{array}{l}\text { Атлетика } \\
\text { Фудбал } \\
\text { Одбојка }\end{array}$ & $\begin{array}{c}\text { Атлетика } \\
\text { Фудбал } \\
\text { Одбојка } \\
\text { Ритмичка } \\
\text { гимнастика }\end{array}$ & $\begin{array}{l}\text { ОШ „,III кр. } \\
\text { батаљон” }\end{array}$ & $\begin{array}{c}\text { Аллетика } \\
\text { Пливање } \\
\text { Фудбал }\end{array}$ & $\begin{array}{c}\text { Одбојка } \\
\text { Пливање } \\
\text { Атлетика } \\
\text { Гимнастика }\end{array}$ \\
\hline УКУПНО 11 & 37 & 33 & УКУПНО 11 & 22 & 17 \\
\hline
\end{tabular}


У узорку школа постоји 59 спортских секција за дечаке, а најзаступљенија спортска грана је атлетика у 11 школа, фудбал у 10 и кошарка у 9 школа. Одбојка је заступљена у 7 школа и пливање у 5 , а затим стони тенис у 3 , стрељаштво у 2 , шах и гимнастика у 1 школи, џудо и теквондо су спортови у секцијама 1 школе (Табела 4).

Када је реч о спортским секцијама за девојчице, у школама постоји 50 спортских секција, од тога: атлетска у 11 , одбојкашка у 10 , фудбалска у 6 , пливачка и ритмичко гимнастичка у 5 школа. Девојчице кошарку могу да тренирају у 3 школе, као и стони тенис, а стрељаштво, рукомет и шах у по 1 школи (Табела 4).

Табела 5. Сйорйске гране у сйорйским секиијама у йрвом ииклусу

\begin{tabular}{|c|c|c|c|c|c|}
\hline ШКОЛА & $\begin{array}{c}\text { Спортске } \\
\text { секције / } \\
\text { дечаци }\end{array}$ & $\begin{array}{c}\text { Спортске } \\
\text { секција } \\
\text { /девојчице }\end{array}$ & $\begin{array}{c}\text { Термини } \\
\text { за часове } \\
\text { секције }\end{array}$ & $\begin{array}{c}\text { Учешһе на } \\
\text { градском } \\
\text { такмичењу }\end{array}$ & $\begin{array}{c}\text { Број } \\
\text { наставника } \\
\text { разредне } \\
\text { наставе }\end{array}$ \\
\hline ОШ „Н Н. Недельковић” & Фудбал & $\begin{array}{c}\text { Спортска } \\
\text { секщија }\end{array}$ & да & не & 2 \\
\hline ОШ „Ђ. Јакшшћ” & Шах & $\begin{array}{c}\text { Ритмичка } \\
\text { гимнастика } \\
\text { Плес }\end{array}$ & да & не & 7 \\
\hline ОІІ „Р. Домановић” & Фудбал & I & да & $\mathrm{He}$ & 2 \\
\hline ОII „III кг.батаљон” & Фудбал & I & да & не & 1 \\
\hline УКУПНО & 4 & 3 & / & / & 12 \\
\hline
\end{tabular}

Интересантан је податак који је добијен у овом истраживању, да у првом циклусу основног образовања, у три школе постоје задужења наставника разредне наставе за рад фудбалске спортске секције за дечаке и шах (Табела 5). Што се тиче спортских секција за девојчице, у 1 школи је организована спортска секција (непозната спортска грана), у још 1 школи постоје секције за ритмичку гимнастику и плес. Од укупно 341 наставника у првом циклусу образовања и васпитања само 12 $(3,57 \%)$ има задужење за рад са спортским секцијама.

Табела б. Проченай обухвайа ученика ӣо йолу у сйорйским секцијама у йрвом циклусу

\begin{tabular}{ccccc}
\hline \multirow{2}{*}{ ШколА } & \multicolumn{2}{c}{ ПРВИ ЦИклУС } & \multicolumn{2}{c}{ \% обухвата ученика по полу } \\
\cline { 2 - 5 } & $\mathbf{M}$ & Ж & М & Ж \\
\hline ОШ „М. Симовић” & 64 & 83 & 0 & 0 \\
ОШ „М. Тодоровић” & 224 & 230 & 0 & 0 \\
ОШ „Свети Сава” & 138 & 117 & $14 / 7,73 \%$ & $15 / 8,52 \%$ \\
ОШ „Н. Недельковић” & 181 & 176 & 0 & 0
\end{tabular}




\begin{tabular}{|c|c|c|c|c|}
\hline ОШ „С. Марковић” & 235 & 206 & 0 & 0 \\
\hline ОШ „С. Младеновић” & 103 & 91 & 0 & 0 \\
\hline ОШ „Ж. Цивац” & 92 & 85 & 0 & 0 \\
\hline ОШ „Р. Домановић” & 221 & 246 & $14 / 6,33 \%$ & 0 \\
\hline ОШ „19. Октобар” & 63 & 69 & 0 & 0 \\
\hline ОШ „21. Октобар” & 161 & 171 & 0 & 0 \\
\hline ОШ „Д.Л. Шпанац" & 120 & 102 & 0 & 0 \\
\hline ОПІ „С. Сремчевић” & 256 & 255 & 0 & 0 \\
\hline ОШ „Д. Михаиловић” & 168 & 186 & 0 & 0 \\
\hline ОШ „В. Стефановић” & 303 & 260 & 0 & 0 \\
\hline ОШ „П.С. Поповић” & 35 & 42 & 0 & 0 \\
\hline ОШ „Ј. Поповић” & 153 & 147 & 0 & 0 \\
\hline ОШІ „Д. Обрадовић” & 89 & 89 & 0 & 0 \\
\hline ОШІ „ШІ кг.батаљон” & 181 & 185 & $14 / 7,73 \%$ & 0 \\
\hline ОШ „М. Станојловић” & 165 & 191 & 0 & 0 \\
\hline ОШ „Ђ. Јакшић” & 74 & 80 & $5 / 6,75 \%$ & $22 / 27,5 \%$ \\
\hline ОШ „Ј. Ђатић” & 32 & 19 & 0 & 0 \\
\hline УКУПНО & 3319 & 3355 & 47 & 37 \\
\hline$\%$ обухваћености & $100 \%$ & $100 \%$ & $1,41 \%$ & $1,10 \%$ \\
\hline
\end{tabular}

У првом циклусу образовања изузетно је мала укљученост ученика у спортске секције, само $1.41 \%$ дечака и $1.10 \%$ девојчица (Табела 6). Укљученост ученика у спортске секције у другом циклусу образовања је знатно већа, односно 20,35\% дечака и 16,52\% девојчица је укључено у секције (Табела 7).

Табела 7. Проценай обухвайа ученика йо йолу у сйорйским секцијама икола у другом циклусу

\begin{tabular}{ccccc}
\hline \multirow{2}{*}{ школА } & \multicolumn{2}{c}{ ДРУГИ ЦиклуС } & \multicolumn{2}{c}{ \% обухвата ученика по полу } \\
\cline { 2 - 5 } & $\mathbf{M}$ & ж & М & ж \\
\hline ОШ „М. Симовић” & 73 & 90 & $26 / 35,62$ & $25 / 27,78 \%$ \\
ОШ „М. Тодоровић” & 243 & 233 & $48 / 19,75 \%$ & $40 / 17,17 \%$ \\
ОШ „Свети Сава” & 149 & 126 & $28 / 18,79 \%$ & $0 / 0 \%$ \\
ОШ „Н. Недельковић” & 127 & 154 & $34 / 26,77 \%$ & $0 / 0 \%$ \\
ОШ „М. Јовановић” & 345 & 349 & $62 / 17,97 \%$ & $59 / 16,90 \%$
\end{tabular}




\begin{tabular}{ccccc} 
ОШ „С. Марковић” & 279 & 313 & $47 / 16,85 \%$ & $60 / 19,17 \%$ \\
ОШ „С. Младеновић” & 114 & 104 & $26 / 22,80 \%$ & $24 / 23,07 \%$ \\
ОШ „Ж. Цивац” & 95 & 95 & $4 / 4,21 \%$ & $4 / 4,21 \%$ \\
ОШ „Р. Домановић” & 215 & 210 & $30 / 13,95 \%$ & $0 / 0 \%$ \\
ОШ „19.Октобар” & 55 & 45 & $0 / 0 \%$ & $0 / 0 \%$ \\
ОШ „,21. Октобар” & 181 & 166 & $30 / 16,57 \%$ & $26 / 15,66 \%$ \\
ОШ „Д.Л. Шпанац” & 143 & 95 & $29 / 20,80 \%$ & $17 / 17,90 \%$ \\
ОШ „С. Сремчевић” & 270 & 286 & $58 / 21,48 \%$ & $26 / 9,09 \%$ \\
ОШ „Д. Михаиловић & 123 & 112 & $20 / 16,26 \%$ & $32 / 28,57 \%$ \\
ОШ „В. Стефановић” & 273 & 282 & $50 / 18,32$ & $50 / 17,73 \%$ \\
ОШ „П.С. Поповић” & 24 & 25 & $0 / 0 \%$ & $6 / 24,00 \%$ \\
ОШ „Ј. Поповић” & 149 & 135 & $53 / 35,57 \%$ & $47 / 34,81 \%$ \\
ОШ „Д. Обрадовић” & 79 & 78 & $23 / 29,11 \%$ & $20 / 25,64 \%$ \\
ОШ „ІІ кг. батаљон” & 156 & 186 & $35 / 22,43 \%$ & $42 / 22,58 \%$ \\
ОШ „ М. Станојловић” & 220 & 169 & $12 / 54,54 \%$ & $20 / 11,83 \%$ \\
ОШ „П. Јакшић” & 112 & 96 & $57 / 50,89 \%$ & $43 / 44,79 \%$ \\
ОШ „Ј. Ђатић” & 47 & 65 & $23 / 48,94 \%$ & $23 / 35,38 \%$ \\
\% обухваћености & $100 \%$ & 3414 & 695 & 564 \\
\hline
\end{tabular}

Укљученосии иколе у сисиемм йакмичења Градског савеза за иколски сйорй

Број школа, као и полна структура ученика који узимају учешће на градском такмичењу из дванаест спортских грана, упућује да се највећи број школа пријављује за такмичење из следећих спортских грана: атлетика 17 школау женској и 15 у мушкој конкуренцији, кошарка 13 школа у мушкој и 8 у женској конкуренцији, одбојка 14 школа у женској и 5 у мушкој конкуренцији, мали фудбал 17 школа у мушкој и 7 у женској конкуренцији, рукомет 5 школа у мушкој и 3 у женској конкуренцији (Табела 8).

За градско првенство у пливању пријављено је 15 школа у мушкој и 14 у женској конкуренцији. Пријаву за такмичење у стоном тенису поднело је 11 школа у мушкој и 7 у женској конкуренцији. Екипу за такмичење у стрељаштву пријавило je 5 школа у мушкој и 3 у женској конкуренцији. За градско такмичење у спортској гимнастици пријавиле су се 2 школе у женској конкуренцији. Три школе су се пријавиле за Мале олимпијске игре. За такмичење у каратеу пријавиле су се три школе у женској и мушкој конкуренцији. Пријава за такмичење у џудоу није било. За такмичење у тенису $(2002,2003$, и 2004. годиште) пријавиле су се три школе у 
женској и мушкој конкуренцији. Три школе или 13,64\% нису пријавиле екипе за такмичење (бојкотују такмичења Градског савеза за школски спорт) (Табела 9).

Табела 8. Пријава икола за йакмичење на градском нивоу у сйорйским играма

\begin{tabular}{|c|c|c|c|c|c|c|c|c|}
\hline \multirow{2}{*}{ ШКОЛА } & \multicolumn{2}{|c|}{ КОШАРКА } & \multicolumn{2}{|c|}{ ОДБОЛКА } & \multicolumn{2}{|c|}{ РУКОМЕТ } & \multicolumn{2}{|c|}{$\begin{array}{c}\text { МАЛИ } \\
\text { ФУДБАЛ }\end{array}$} \\
\hline & $\mathbf{M}$ & Ж & $\mathbf{M}$ & Ж & $\mathbf{M}$ & Ж & $\mathbf{M}$ & Ж \\
\hline ОІІ „М. Симовић” & + & & & + & & & + & \\
\hline ОШІ „М. Тодоровић” & & + & & + & & & + & \\
\hline ОШ „Свети Сава” & + & & & + & & & + & \\
\hline ОШ „Н. Недељковић” & & & + & + & & & + & \\
\hline ОШ „М. Јовановић” & + & + & + & + & + & + & & \\
\hline OII „С. Марковић” & + & & & + & & & + & \\
\hline ОІІ „С. Младеновић” & + & + & & & & & + & + \\
\hline ОШ „Ж. Дивац" & & & & & & & + & \\
\hline ОШ „Р. Домановић” & + & + & & + & + & & + & \\
\hline ОШ „,19. Октобар” & 0 & 0 & 0 & 0 & 0 & 0 & 0 & 0 \\
\hline ОІІ „,21. Октобар” & + & + & + & & & & + & + \\
\hline ОШ „Д. Л. Шпанац” & & & & & & & + & + \\
\hline ОШ „С. Сремчевић” & + & & & + & + & & + & \\
\hline ОШ ,„Д. Михаиловић & + & & & + & & & + & \\
\hline ОШ „В. Стефановић” & + & + & + & + & + & + & + & + \\
\hline ОШ „П.С. Поповић” & & & & & & & + & \\
\hline ОШ „Ј. Поповић” & + & + & & + & + & + & + & + \\
\hline ОШ „Д. Обрадовић" & & & & + & & & & + \\
\hline ОШ „III кг. батаљон” & + & & + & + & & & + & \\
\hline OІІ „, М. Станојловић” & + & + & & + & & & + & + \\
\hline ОШІ „Ћ. Јакшпић” & 0 & 0 & 0 & 0 & 0 & 0 & 0 & 0 \\
\hline ОШ „Ј. 'Һатић” & 0 & 0 & 0 & 0 & 0 & 0 & 0 & 0 \\
\hline УКУПНО ЕКИПА & 13 & 8 & 5 & 14 & 5 & 3 & 17 & 7 \\
\hline
\end{tabular}


Табела 9. Пријава школа за йакмичење на градском нивоу у индивидуалним сйорйовима

\begin{tabular}{|c|c|c|c|c|c|c|c|c|c|c|}
\hline \multirow{2}{*}{ ІІкоЛА } & \multicolumn{2}{|c|}{$\begin{array}{l}\text { СТОНИ } \\
\text { ТЕНИС }\end{array}$} & \multicolumn{2}{|c|}{ ПЛИВАњЕ } & \multicolumn{2}{|c|}{ СТРЕ.ЉАШТВО } & \multicolumn{2}{|c|}{$\begin{array}{c}\text { СПОРТСКА } \\
\text { ГИМНАСТИКА }\end{array}$} & \multicolumn{2}{|c|}{ АТЛЕТИКА } \\
\hline & $\mathbf{M}$ & Ж & $\mathbf{M}$ & Ж & $\mathbf{M}$ & Ж & $\mathbf{M}$ & Ж & $\mathbf{M}$ & Ж \\
\hline ОІІ „М. Симовић” & + & + & + & + & & & & & + & + \\
\hline ОШ „М. Тодоровић” & + & & + & + & + & & & & + & + \\
\hline ОШ „Свети Сава” & & & + & + & & & & & + & + \\
\hline ОШ „Н. Недељковић” & & & + & + & + & + & & & + & + \\
\hline ОІІ „М. Јовановић” & + & & + & + & & & & & & \\
\hline OII „С. Марковић” & + & + & & & + & + & & & + & + \\
\hline ОШ „С. Младеновић” & + & & & & + & & & & + & + \\
\hline ОШ „Ж. Дивац” & + & + & + & + & & & & & + & + \\
\hline ОШ „Р. Домановић” & + & + & + & + & & & & + & & \\
\hline ОІІ „,19.Октобар” & 0 & 0 & 0 & 0 & 0 & 0 & 0 & 0 & 0 & 0 \\
\hline ОШІ „21. Октобар” & & & & & & & & & & + \\
\hline ОШ „Д.Л. Шпанац” & + & + & + & + & + & + & & & + & + \\
\hline ОШ „С. Сремчевић” & + & & + & + & & & & & + & + \\
\hline ОШ „Д. Михаиловић & & & + & + & & & & & + & + \\
\hline ОІІ „В. Стефановић” & & & + & + & & & & & + & + \\
\hline ОШ „П.С. Поповић” & & & & & & & & & + & + \\
\hline ОШ „,. Поповић” & + & + & + & + & & & & & + & + \\
\hline ОШ „Д. Обрадовић” & + & + & + & & & & & & & + \\
\hline ОШ „III кг. батаљон” & & & + & + & & & & + & + & + \\
\hline $\begin{array}{c}\text { ОIII „, М. } \\
\text { Станојловић” }\end{array}$ & & & + & + & & & & & + & + \\
\hline ОШ „Ђ. Јакшић” & 0 & 0 & 0 & 0 & 0 & 0 & 0 & 0 & 0 & 0 \\
\hline ОШ „,. Ђатић” & 0 & 0 & 0 & 0 & 0 & 0 & 0 & 0 & 0 & 0 \\
\hline УКУПНО ЕКИПА & 11 & 7 & 15 & 14 & 5 & 3 & 0 & 2 & 15 & 17 \\
\hline
\end{tabular}




\section{Дискусија}

Анализа добијених података указује да је у првом циклусу образовања и васпитања, од 3319 дечака само њих $47(1,41 \%)$ и $37(1,10 \%)$ девојчица, од укупно 3355 јукључено у спортске секције. Од укупно 341 наставника у првом циклусу образовања и васпитања само $12(3,57 \%)$ има задужење за рад са спортским секцијама. Иако постоје сви законски предуслови да наставници у првом циклусу основног образовања у структури непосредног рада са ученицима имају и задужења за рад спортских секција, то није усвојена пракса у школама. У погледу организације васпитно-образовног рада у већем броју школа омогућено је коришћење сале за физичко васпитање и спортских терена за рад спортских секција ученика првог циклуса. Интересантан је податак који је добијен овим истраживањем да ни у једној школи није организовано школско спортско такмичење за ученике овог циклуса образовања, а да су се 3 школе пријавиле да желе да се такмиче на Малим олимпијским играма у организацији градског савеза за школски спорт које нису реализоване због малог броја пријављених школа. Наставну област физичког васпитања у школама обухваћеним истраживањем реализују 49 наставника са прописаном врстом и степеном стучне спреме. Велика већина наставника (43) има задужење 1 час недељно, 2 наставника 2 часа недељно за рад са спортском секцијом и свима су обезбеђени тремини за рад. Један број наставника физичког васпитања (4) у структури непосредног рада са ученицима нема задужења за рад са спортским секцијама. Када је реч о опремљености школа затвореним простором за реализацију наставне области физичког васпитања, а самим тим и спорта у школи, резултати показују да 14 школа има салу за физичко васпитање, 4 школе користе адаптирани простор, а 4 немају затворен простор за реализацију наставе. У погледу опремљености школа отвореним спортским теренима ситуација је повољнија, јер 16 школа има терен и голове за рукомет, док 6 школа нема услове за овај спорт. Кошаркашки терен са кошевима има 19 школа. Терен са конструкцијом и мрежом за одбојку има 13 школа. Две школе имају јаму за скокове и затворен базен малих димензија. Разматарјући наведене материјалне услове, може се констатовати да су на задовољавајућем нивоу што се тиче простора. Број расположивих лопти за спортске игре није у складу са Правилником о нормаииивима иколског йросйора, ойрема и настиавних средсииава за основну иколу (Просветни гласник, 1990). У односу на прописан број лопти за спортске игре (15), број лопти за кошарку и рукомет се креће од 2 до 20 по школи, за одбојку од 1 до 16, и за фудбал од 1 до 10 лопти. Спроведено истраживање указује да је од укупно 3472 дечака другог циклуса у 59 спортских секција укључено 695 (20,35\%), а од 3414 девојчица у 50 спортских секција укључено je 564 (16,52\%). Ово истраживање је потврдило да сваки пети дечак има прилику у школи да се бави спортом кроз рад спортске секције а да је свака шеста девојчица укључена у неку од спортских секција. Број ученика укључених у рад спортских секција и у такмичења унутар школе значајан је показатељ стања школске праксе у реализацији спорта у школи. Најзаступљенија спортска грана је атлетика у 11 школа у мушкој и женској секцији, кошарка у 12 школа, фудбал у 16 школа, одбојка у 17 школа, ритмичка гимнастика у 5 школа, стони тенис у 6 школа, стрељаштво у 3 
школе, рукомет у 1 школи, гимнастика у 1 школи, као и џудо и теквондо, док се шах реализује као спортска секција у 2 школе. Индикативан је податак да у 10 школа постоји пливачка секција, а две школе имају врло мали базен за обуку непливача, где није могуће тренирати пливање за такмичарски наступ. Најзаступљенија спортска игра у реализацији унутаршколских такмичења је мали фудбал у 11 школа, затим следи обојка у 8 школа, кошарка у 5, стони тенис у 2 и атлетика у 1 школи. Школе нису усвојиле праксу да организују такмичење из вежби на справама и тлу, које је обавезно по програму. Истраживање је показало да школе не реализују школско такмичење у гимнастици, да само 1 школа реализује такмичење у атлетици, 7 школа не реализују јесењи и пролећни крос. Скоро једна трећина школа $(27,24 \%)$ не раелизују школска спортска такмичења која су прописана наставним планом и програмом физичког васпитања.

На основу извештаја/евиденције Градског савеза за школски спорт у школској 2015/2016. години на спортским такмичењима наступило је у пливању 17 школа у мушкој конкуренцији са 152 такмичара и 15 школа у женској конкуренцији уз учешће 132 такмичарке. Истраживање је показало да је најмасовније такмичење основаца у пливању, на којем је наступило 284 такмичара од укупно 730, који су се такмичили у свим спортским гранама, током школске 2015/16. године, што чини $38,90 \%$ свих такмичара. На такмичењу у атлетици наступило је 17 школа у мушкој конкуренцији са 93 такмичара, у женској конкуренцији, 15 школа са 78 такмичарки, што је $23,42 \%$ од свих такмичара који су наступали у претходној школској години. Идикативан је податак, да 62,32\% свих такмичара, који су наступили на такмичењима основних школа града Крагујевца, чине такмичари у пливању и атлетици. Једна школа организује школско такмичење у атлетици, а за учешће на градском такмичењу у пливању потребан је одговарајући резултат/време. Школе су се такмичиле у следећим спортовима: у одбојци, 3 школе у мушкој конкуренцији уз учешће 35 такмичара и 12 школа у женској конкурецији са 138 такмичарки; у стоном тенису, такмичило се 8 школа у мушкој конкуренцији и 4 у женској конкуренцији, уз учешће 24 такмичара и 10 такмичарки у појединачној конкуренцији и 6 школа у екипној конкуренцији са 12 такмичара, као и 4 школе у женској конкуренцији са наступом 8 такмичарки у екипној конкуренцији; у гимнастици, у мушкој конкуренциј наступила је 1 школа са 1 такмичаром, док је учешће у женској конкуренцији узело 6 школа са 18 такмичарки; у стрељаштву је наступило 4 школе са екипом у мушкој конкуренцији и 12 такмичара и 2 школе у женској конкуренцији са 3 такмичарке, као и по 6 такмичара/ки у појединачној конкуренцији. Укупан проценат учешћа школске популације на такмичењима у организацији Градског савеза за школски спорт у школској 2015/16. години у мушкој конкуренцији је 4,90\%, док је тај проценат у женској конкуренцији 5,84\%. Овај резултат није у складу са резултатима других истраживања, која су указала да је код дечака израженије интересовање за бављење спортом. Презентовани резултати истраживања се односе на укупну школску популацију у основном образовању града Крагујевца, а школске спортске секције које се такмиче чине ученици седмог и осмог разреда који су већ укључени у тренажно-такмичарски процес у спортским клубовима. 


\section{Закључак}

Један од посебних циљева Стратегије развоја спорта у Републици Србији је повеђање броја спортских секција и других ваннаставних и рекреативних активности у оквиру школског спорта. Међу посебне циљеве предвиђено је и повећано учешће ученика на школским такмичењима, приредбама и манифестацијама. С обзиром на то да настава физичког васпитања обухвата укупну популацију младих укључених у образовно-васпитни систем код нас, она представља повољно образовно и васпитно окружење за развој позитивног става према физичкој активности и спорту. Уз редовну наставу физичког васпитања и наставу обавезног изборног предмета физичко васпитање -изабрани спорт, школска спортска такмичења, спортске приредбе и манифестације могу и морају значајно употпунити дефицит физичког вежбања ученика. Притом је важно да се сви ученици школе укључе у спортска такмичења без посебне селекције и ограничења.

Школа у оквиру школског програма, сачињава програм школског спорта и спортских активности, у који треба уврстити сва такмичења прописана планом и програмом предмета физичко васпитање и физичко васпитање - изабрани спорт, програм недеље школског спорта, спортске манифестације и приредбе у организацији локалне самоуправе и план наступа на такмичењима у организацији градског савеза за школски спорт. Програмом сарадње са јединицом локалне самоуправе школа треба да покрене значајније укључивање локалне самоуправе у планирању и временској усклађености учешћа ученика на спортским приредбама и манифестацијама у организацији локалне заједнице. Програмом сарадње са породицом неопходно је планирати учешће родитеља и деце на спортским приредбама и манифестацијама у оквиру школе или локалне самоуправе уз могућност да бесплатно користе спортске терене и салу школе за своје рекреативне и спортске активности. Сачињен план и програм спортских такмичења, приредби и манифестација треба да постане саставни део програма заштите ученика од насиља, злостављања, занемаривања и дискриминације, којим се промовише неговање културе спортског понашања, фер плеја, сарадње, толеранције и поштовања различитости на спортским теренима и поред њих. У оквиру развојног плана, један од развојних циљева школе треба да буде повећање броја ученика у спортским секцијама и веће учешће ученика на такмичењима у оквиру градског савеза за школски спорт, као и учешће ученика и родитеља на спортским манифестацијам у организацији локалне самоуправе. Такође, неопходно је обновити школска спортска душтва која треба да преузму реализацију свих спортских такмичења, манифестација и приредби у школи и локалној заједници, уз учешће родитеља.

Полазећи од значај физичког васпитања и спорта у друштву, имајући у виду његову социјалну и здравствену улогу у неговању и ааању здравља нације, неопходно је формирати међуресорни тим у чији састав би ушли представници Министарства просвете са задатком координације активности за унапређење наставе физичког васпитања и школског спорта. 


\section{Литература}

Закон о сйорйу, Службени гласник РС - Просветни гласник, бр.24(2011)

Закон о основном образовану и васйийану (20139. Служб́ени гласник РС - Просветни гласник , бр.55/2013)

Предлогмера за унайређивање насйаве физичког васйийања, (2013), Национални просветни савет, Београд.

Оквирни акциони йлан за ирревенцију насиља у образовно-васйийним усйановама, (2009) Министарство просвете Републике Србије, Београд.

Правилник о крийеријумима и сйандардима за финансирање усйанове која обавља

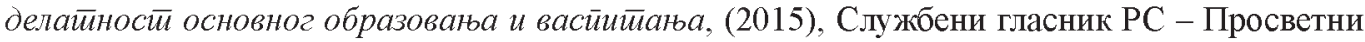
гласник, бр. 36/2015)

Правилник о насйавном йрограму за йейи разред основног образовања и васйийања, Службени гласник РС - Просветни гласник, бр. 6/2007)

Правилиик о насйавном йрограму за иесиии разред основног образоваьа и васииийаьа (2008), Службени гласник РС - Просветни гласник, бр. 5/2008)

Правилник о насйавном йрограму за седми разред основног образовања и васйийања (2009), Службенни гласник РС - Просветни гласни , бр. 6./2009)

Правилник о насииавном йрограму за осми разред основног образовања и васиййьа, Службени гласник РС - Просветни гласник, бр. 2/2010)

Стратегија развоја спорта у Републици Србији 2014. до 2018. године.

Национална стартегија за борбу против насиља и недоличног понашања на спортским приредбама за период од 2013. до 2018. године.

Извеиийај о осйвариваюу йрава дейейа у Рейублии Србији из угла деце и младих (2013), Центар за права детета, Београд.

Национална сйрайегија за младе (2005), Службеени гласник РС, бр.55/05;71/05 - исправка и 101/07).

Радојевић, J. (2011). Стандарди у функцији унпређивања квалитета физичког васпитања. Физичка кулйура, 65(1), 70-83.

McDeviit, t.m.\& Ormrod,J.E. (2002). Child Development and Educatio, Upper Saddli River,NJ: Пearson Education.

Brettschneider W-D., Brandl-Bredenbeck H.P. (2008). Physical education and education through sport in Germany. In Klein, G., Hardman, K., ( Eds.). Physical Education and Sport Educatio in Europien Union (pp.145-161). Paris: Edition Revue EP.S.

Уредбе о Националном програму превенције, лечења и контроле кардиоваскуларних болести у Републици Србији до 2020. године.

Здравље сииановника Србије - аналийичка сйудија 1997-2007. (2008), Институт за јавно здравље Србије „др Милан Јовановић Батут”, Београд. 